\title{
ANTIFUNGAL ACTIVITIES OF ETHANOL EXTRACT OF ROSEMARY LEAF (Rosemarinus officinalis L.) AGAINST Candida albicans
}

\author{
Dewa Ayu Made Adnya Swari ${ }^{1 *}$, I Wayan Martadi Santika ${ }^{2}$, I Gusti Made Aman ${ }^{1}$ \\ ${ }^{1}$ Clinical Pharmacy, International Bali University, Bali, Indonesia \\ ${ }^{2}$ Pharmacy Department, Universitas Udayana, Bali-Indonesia \\ Corresponding author email: swariadnya@gmail.com
}

\begin{abstract}
Background: This study was a preliminary study aimed to investigating the in vitro activity of rosmarinic acid contained on Rosemary leaves (Rosemarinus officinalis L.) on the Candida albicans. Rosmarinic acid can be an inhibitor of the RTPase enzyme in the fungus Candida albicans. Objective: This study is expected to provide information in the development of science about the antifungal activity of ethanol extract of Rosemary leave (Rosmarinus officinalis L.) againsts C.albicans. The recent research was an laboratory experimental. Experiments on an ethanol extract of Rosemary leaves (Rosemarinus officinalis L.) and posttest design of the control group. Methods: The extraction method used in this study was a multilevel extraction method. The antifungal activity testing method uses discs and MIC methods. Replication was done six times at two concentration namely, $80 \%$ (b/v) and 100\% for each measurement. Results: The data analysis was carried out using SPSS with $95 \%$ of confidence level with the Kruskal Wallis analysis then completed with the Mann Whitney U test. The results of the MIC experiment showed all the various concentrations of ethanol extract performed Candida albicans growth on the surface of the media. Extract with $80 \%(\mathrm{~b} / \mathrm{v})$ concentration showed greater antifungal activity. Furthermore the MIC was shown by $80 \%$ (b/v) concentration of the ethanol extract of Rosemary leaves against Candida albicans. The test results of the antifungal activity of the Rosemary leaf ethanol extract showed the presence of inhibitory diameter in the ethanol extract of the Rosemary leaf concentration of $80 \%(\mathrm{~b} / \mathrm{v})$ with a mean \pm SD of $10.6 \pm 0.57735$ and RSD of $5.774 \%$. Conclusion: The ethanol extract of Rosemary leaves (Rosmarinus officinalis L.) has an inhibitory effect on the fungus Candida albicans at a concentration of $80 \%(\mathrm{~b} / \mathrm{v})$.
\end{abstract}

Keywords: Antifungal activity, Candida albicans, Rosemary, RTPase, ethanol extract

\section{INTRODUCTION}

Candida albicans belongs to the phylum ascomycetes with the class of saccharomycetes. ${ }^{[1]}$ Candida albicans is a yeast-type fungus, which forms yeast cells and pseudohyphae. Candida albicans are often found in the human body as a normal microflora and can turn into a pathogen if there are risk factors such as decreased immunity, endocrine disorders, smokers and chemotherapy. Candida albicans in the oral cavity, which often cause opportunistic infections, are referred to as oral candidiasis or thrush. ${ }^{[2]}$ Candida albicans species are also a major cause of candidal infection (bloodstream infection). Nosocomial Kandemia has become an important infection not only because of an increased 
incidence (40\%) but also because of its high mortality rate. ${ }^{[3]}$

The choice of drugs for the treatment of Candida albicans infection is not as much as an antibacterial treatment therapy. One of the conventional antifungal drugs that are widely used in the treatment of infections in Candida albicans is the azole antifungal such as fluconazole, voriconazole, itraconazole, ketoconazole. Most azole (antifungal) has various limitations on side effects such as rashes, itching, diarrhea, abdominal pain, redness of the skin to liver damage. This problem is exacerbated by the emergence of C. Albicans strains that are resistant to azole antifungal groups. ${ }^{[4]}$ This problem underlines the importance of developing new antifungal drugs for the treatment of C. Albicans infection.

Recent research shows that Rosmarinic acid compounds can inhibit the work of the TTM-RTPase enzyme from the parasite Trypanosoma brucei. ${ }^{[5]}$ TTM-RTPase enzyme in the parasite Trypanosoma brucei has a similar structure, active site and working mechanism with the TTM-RTPase enzyme from C.Albicans. So it is suspected that Rosmarinic acid can also inhibit the work of the TTM-RTPase C. Albicans enzyme. So that these compounds can be candidates for the development of new antifungal drugs. ${ }^{[5]}$ But there is no adequate mechanism for synthesizing this compound in the laboratory so that it has limitations in the supply of this compound as a raw material for medicine. In addition, there has also been no testing and development of these compounds as new antifungal drugs.

Rosmarinic acid is a compound that can be found in nature, especially in the leaves of the Rosemary (Rosmarinus officinalis L.) plant. This compound is soluble in ethanol. This study aims to scientifically test the antifungal activity of ethanol extract of Rosemary leaves against the fungus $\mathrm{C}$. Albicans. The test was started by testing the Minimum Inhibitory Level (MIC) by knowing the smallest concentration of ethanol extract, which was able to inhibit the growth of C.albicans. The test was continued with an antifungal activity test, to determine the inhibition of various concentrations of ethanol extract on C. Albicans by the diffusion method of a paper disk.

\section{METHODS}

The recent research was an laboratory experimental. The design of the antifungal activity test study in this study was post-test only control group design. This study used ethanol extract from Rosemary leaves extracted with $70 \%$ ethanol. Negative controls used were 1\% CMC solution, meanwhile $200 \mathrm{mg}$ generic ketoconazole tablet as a positive control. The number of repetitions in the experiment according to calculations using Federer's formula was repeated six times.

\section{Research procedure}

This research includes several stages, including stages:

- Sortating Rosemary plant material

- Extraction with multilevel maceration method

- Preparation the testing solutions with various concentrations

- Making potato dextrose agar media

- Planting the inoculum with the streak plate technique

- Making negative control solutions

- Determination of the minimum inhibition concentration (MIC)

- Testing of antifungal activities

The method of the data analysis used in this study was the Kruskal Wallis analysis method. Statistical testing is continued to Post-Hoc to test hypotheses using the Mann Whitney U test. 


\section{RESULTS}

\section{Origin Plant Identification Results}

Plant determination was carried out at the Indonesian Institute of Sciences, UPT, Eka Karya Botanical Gardens, Bedugul Botanical Gardens, Bali. The results of the determination show that this type of plant is Rosemarinus officinalis $L$.

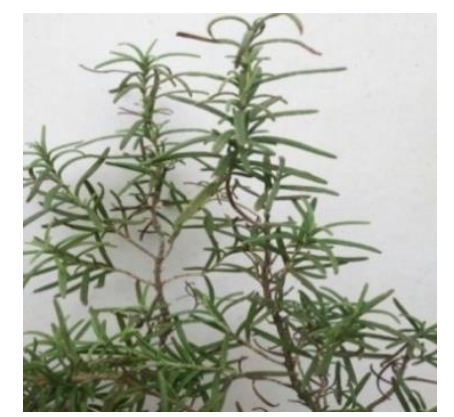

Figure 1 Rosemary Plant

\section{Results of Making Ethanol Extract of Rosemary Leaves}

The material used in this study was Rosemarynus officinalis L. leaves obtained from the Candido Agro Herbal-Pasuruan area. The $1.5 \mathrm{Kg}$ of fresh materials of Rosemarynus officinalis L. leaves produced $1 \mathrm{~kg}$ of dry powder.

\section{Minimum Inhibitory Concentration Results}

Observation results in antifungal effectiveness is shown in Figure 4, while the MIC results of the ethanol extract of Rosemary leaves (Rosemarinus officinalis L.) can be seen in Figure 2 and Table 5.

\section{DISCUSSION}

The determination of the Rosemary plant used in this study was carried at the UPT Plant Conservation Center Eka Karya Botanical Garden, LIPI, Bedugul. The purpose of the determination of certain plant is to determine the truth of the identity of the plant so that errors in the collection of materials to be studied can be avoided. The results of the determination of the Rosemary plant show that the herbs used are indeed
Rosemarinus officinalis L. Fresh Rosemary leaves (Rosmarinus officinalis L.) was obtained from the Candido Agro HerbalPasuruan area. Furthermore, the drying of Rosemary leaves is done by using the oven at $45^{\circ}-50^{\circ} \mathrm{C}$ for 48 hours. The purpose of the material drying using an oven is to maintain the quality of Rosmarinic acid contained in Rosemary leaves so that it is not damaged by direct sunlight. From $1.5 \mathrm{~kg}$ of fresh plant material, $1 \mathrm{~kg}$ of dried materials was obtained from Rosemary leaves. ${ }^{[7]}$ Rosemary dried leaves were mashed by blending and multilevel extraction.

Ethanol extract of Rosemary leaves (Rosemarinus officinalis L.) was made by means of multilevel maceration methods. As much as $1 \mathrm{~kg}$ of Rosemary leaf powder macerated in a solvent with increased polarity, namely n-hexane, ethyl acetate, and $70 \%$ ethanol. The purpose of this method is to separate rosmarinic acid contained in Rosemary leaf samples from other substances according to their level of polarity. The main constituent of Rosemary (Rosemarinus officinalis L.) leaves, Rosmarinic acid, has solubility, which can dissolve in ethanol solvents but is not soluble in n-hexane and is slightly soluble in ethyl acetate. ${ }^{[6,8]}$ The n-Hexan solvent aims to attract all nonpolar compounds contained in Rosmary leaves while ethyl acetate functions to attract other nonpolar and semipolar compounds. While ethanol serves to attract polar compounds. The extraction sequence is also important to keep rosmarinic acid compounds well extracted.

The results of the examination of ethanol extract of Rosemary leaves (Rosemarinus officinalis L.), which are organoleptic in the form of liquid, reddishbrown color, and the distinctive smell of Rosemary leaves. Phytochemical screening was also carried out in this study, which aims to confirm the content of secondary metabolites from the ethanol extract of Rosemary leaves made. 
Table 1 Results of ethanol extract of Rosemary leaves ( Rosemarinus officinalis $L$. )

\begin{tabular}{clc}
\hline & Organoleptic observation & Result \\
\hline- & Form & Liquid \\
- & Colour & Blackish brown \\
- & Odor & Qupical Rosemary leaves with a hint of ethanol \\
\hline- & Sample Weight (gram) & Result \\
\hline- & Extract Weight (gram) & $1000 \mathrm{~g}$ \\
- & Rendement & $63.1867 \mathrm{~g}$ \\
\hline
\end{tabular}

Table 2 Test Results for Phytochemical Screening

\begin{tabular}{|c|c|c|c|c|}
\hline & Phytochemical Testing & Result & Before & After \\
\hline- & Alkaloids & $\begin{array}{l}(+) \text { Brown precipitate are } \\
\text { formed } \\
\text { (Mayer) }\end{array}$ & & \\
\hline- & Flavonoids & $\begin{array}{l}\text { (+) There is a change in color } \\
\text { from brown to black }\end{array}$ & & \\
\hline- & Terpenoid & $\begin{array}{c}(-) \text { There is no change in color } \\
\text { to red }\end{array}$ & & \\
\hline & Saponin & $\begin{array}{c}(+) \text { Foam with a height of } 1 \mathrm{~cm} \\
\text { is formed }\end{array}$ & & \\
\hline
\end{tabular}

Table 3 Constituent of Main Constituent of Rosemary Leaves

\begin{tabular}{cccccc}
\hline & \multicolumn{5}{c}{ Main constituent (mg/g dry basis of extract) } \\
\cline { 2 - 5 } Extract & Carnosic acid & Carnosol & $\begin{array}{c}\text { Rosmarinic } \\
\text { acid }\end{array}$ & $\begin{array}{c}\text { 12-methxy- } \\
\text { carnosic } \\
\text { acid }\end{array}$ & Methyl Carnosic \\
\hline SFE-40 & $36,7 \pm 1,56^{\mathrm{a}}$ & $12,3 \pm 1,12^{\mathrm{a}}$ & $0,2 \pm 0,11^{\mathrm{a}}$ & $0,6 \pm 0,08^{\mathrm{a}}$ & $0,3 \pm 0,2^{\mathrm{a}}$ \\
SFE-60 & $31,3 \pm 1,26^{\mathrm{b}}$ & $7,5 \pm 0,77^{\mathrm{b}}$ & $3,3 \pm 0,26^{\mathrm{b}}$ & $2,2 \pm 0,27^{\mathrm{b}}$ & $3,1 \pm 0,63^{\mathrm{b}}$ \\
SFE-80 & $30,4 \pm 1,77^{\mathrm{b}}$ & $8,2 \pm 0,87^{\mathrm{b}}$ & $3,2 \pm 0,17^{\mathrm{b}}$ & $2,5 \pm 0,32^{\mathrm{b}}$ & $3,3 \pm 0,23^{\mathrm{b}}$ \\
EtOH & $313,6 \pm 1,07^{\mathrm{c}}$ & $5,4 \pm 0,46^{\mathrm{d}}$ & $2,7 \pm 0,02^{\mathrm{c}}$ & $0,6 \pm 0,13^{\mathrm{c}}$ & $1,2 \pm 0,27^{\mathrm{c}}$ \\
Acetone & $24,7 \pm 1,25^{\mathrm{d}}$ & $3,5 \pm 0,33^{\mathrm{e}}$ & $1,4 \pm 0,06^{\mathrm{d}}$ & $1,4 \pm 0,06^{\mathrm{d}}$ & $2,7 \pm 0,58^{\mathrm{d}}$ \\
\hline
\end{tabular}

Rosemary leaves were treated with supercritical fluid-CO2 at 5,000 psi and 40, 60, and 80 _C. SFEs are indicated as SFE-40, SFE-60, and SFE-80. EtOH, ethanolic extract, acetone, an acetonic extract of rosemary leaf powder ${ }^{[6]}$. Results are presented as mean \pm S.D. (n $1 / 43$ ) for each experiment and were statistically analyzed by one-way ANOVA followed by Duncan's multiple range test. Rows with different superscripts $(\mathrm{a}-\mathrm{c})$ indicate significant differences at a confidence level of $\mathrm{p}<0.05$. 


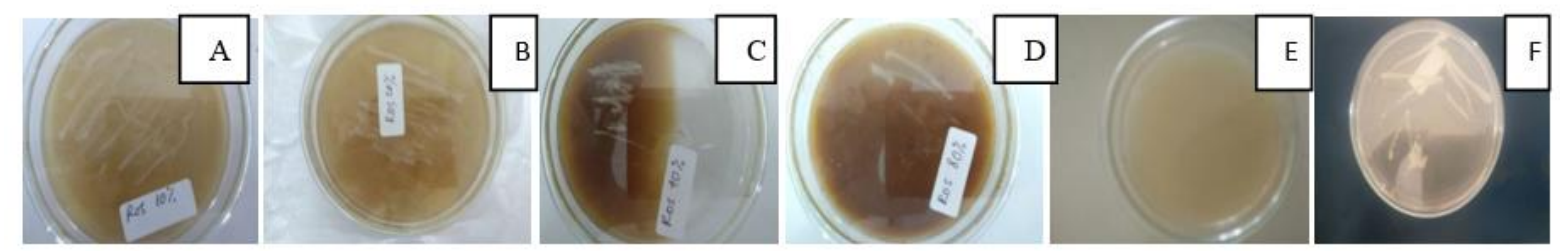

Figure 2. Antifungal effectiveness of Ethanol Extract of Rosemary Leaf, Ethanol extract of Rosemary leaf $10 \%$ (A), Ethanol extract of Rosemary leaf $20 \%$ (B), Ethanol extract of Rosemary leaf $40 \%$ (C), Ethanol extract of Rosemary leaf $80 \%$ (D), Control negative (E), positive control $(\mathbf{F})$.

Table 4 Rosemary Primary Metabolite Content

\begin{tabular}{|c|c|c|c|c|c|}
\hline $\begin{array}{l}\text { Salinity } \\
\text { (Ppm) }\end{array}$ & $\begin{array}{l}\text { Salicylic } \\
\text { acid } \\
(\text { Ppm) }\end{array}$ & $\begin{array}{l}\text { Total phenolic } \\
\text { composition } \\
(\% \text { of } \mathrm{DW})\end{array}$ & $\begin{array}{l}\text { Total chlorophyll } \\
\text { content } \quad \text { (mg/g } \\
\text { DW) }\end{array}$ & $\begin{array}{l}\text { Total } \\
\text { carbohydrates } \\
(\% \mathrm{DW})\end{array}$ & $\begin{array}{l}\text { Proline content }(\mathrm{mg} / \mathrm{g} \\
\text { DW) }\end{array}$ \\
\hline \multirow[t]{4}{*}{640} & 0 & $0,10 \pm 0,01^{\mathrm{e}}$ & $0,82 \pm 0,03^{\mathrm{c}}$ & $18,36 \pm 0,3^{\mathrm{c}}$ & $1,74 \pm 0,05^{\mathrm{f}}$ \\
\hline & 100 & $0,12 \pm 0,00^{\mathrm{d}}$ & $0,84 \pm 0,02^{\mathrm{b}}$ & $18,9 \pm 0,5^{\mathrm{c}}$ & $1,74 \pm 0,04$ \\
\hline & 200 & $0,13 \pm 0,01^{\mathrm{cd}}$ & $0,95 \pm 0,03^{\mathrm{a}}$ & $21,03 \pm 0,3^{\mathrm{a}}$ & $1,79 \pm 0,02$ \\
\hline & 300 & $0,14 \pm 0,00^{\mathrm{c}}$ & $0,92 \pm 0,03^{c}$ & $20,73 \pm 0,6^{\mathrm{a}}$ & $1,88 \pm 0,03^{\mathrm{e}}$ \\
\hline \multirow[t]{4}{*}{2.000} & 0 & $0,15 \pm 0,01^{\mathrm{c}}$ & $0,80 \pm 0,04^{\mathrm{d}}$ & $17,97 \pm 0,7^{\mathrm{e}}$ & $2,18 \pm 0,03^{\mathrm{c}}$ \\
\hline & 100 & $0,11 \pm 0,01^{\mathrm{d}}$ & $0,84 \pm 0,03^{\mathrm{c}}$ & $18,74 \pm 0,2^{\mathrm{c}}$ & $2,17 \pm 0,00^{c}$ \\
\hline & 200 & $0,14 \pm 0,01^{\mathrm{c}}$ & $0,91 \pm 0,05^{\mathrm{a}}$ & $19,33 \pm 0,6^{b}$ & $2,22 \pm 0,01^{\mathrm{bc}}$ \\
\hline & 300 & $0,89 \pm 0,03^{\mathrm{b}}$ & $0,89 \pm 0,02^{\mathrm{b}}$ & $20,02 \pm 0,8^{b c}$ & $2,28 \pm 0,08^{b c}$ \\
\hline \multirow[t]{4}{*}{4000} & 0 & $0,16 \pm 0,01^{\mathrm{c}}$ & $0,78 \pm 0,0^{\mathrm{d}}$ & $17,39 \pm 0,1^{\mathrm{e}}$ & $2,35 \pm 0,05^{\mathrm{b}}$ \\
\hline & 100 & $0,19 \pm 002^{\mathrm{b}}$ & $0,84 \pm 0,03^{c}$ & $18,73 \pm 0,5^{\mathrm{c}}$ & $2,36 \pm 0,05^{b}$ \\
\hline & 200 & $0,19 \pm 0,00^{\mathrm{b}}$ & $0,87 \pm 0,02^{\mathrm{b}}$ & $19,55 \pm 0,7^{\mathrm{b}}$ & $2,39 \pm 0,04^{\mathrm{a}}$ \\
\hline & 300 & $0,24 \pm 0,02^{\mathrm{a}}$ & $0,85 \pm 0,05^{\mathrm{b}}$ & $19,06 \pm 0,8^{c}$ & $2,49 \pm 0,03^{\mathrm{a}}$ \\
\hline
\end{tabular}

Means with different letters within the same column have a significant difference at $\mathrm{P} \leq 0.05$

Table 5 Minimum Inhibitory Concentration Results of ethanol extract of Rosemary leaves (Rosemarinus officinalis L.)

\begin{tabular}{|c|c|c|c|c|c|c|}
\hline \multirow[t]{2}{*}{ Parameter } & \multicolumn{4}{|c|}{ Ethanol extract of Rosemary leaves } & \multirow{2}{*}{$\begin{array}{c}\text { Negative } \\
\text { Control }\end{array}$} & \multirow[t]{2}{*}{ Positive Control } \\
\hline & $10 \%(\mathrm{~b} / \mathrm{v})$ & $20 \%(\mathrm{~b} / \mathrm{v})$ & $40 \%(\mathrm{~b} / \mathrm{v})$ & $80 \%(\mathrm{~b} / \mathrm{v})$ & & \\
\hline While FUNGIs & +++ & ++ & ++ & + & - & +++ \\
\hline
\end{tabular}

\section{Table Information}

$(-) \quad$ : There is no fungal growth

(+) : There is (little) fungal growth

$(++) \quad:$ There is mold growth (medium)

(+++) : There is mold growth (high)

Table 6 Antifungal Activity Test Results

\begin{tabular}{ccccc}
\hline Replication & \multicolumn{4}{c}{ Inhibition diameter $(\mathbf{m m})$} \\
\cline { 2 - 4 } $\mathbf{1}$ & $\mathrm{P} 0$ & $\mathrm{P} 1$ & $\mathrm{P} 2$ & $\mathrm{P} 3$ \\
$\mathbf{2}$ & 0 & 8 & 11 & 0 \\
$\mathbf{3}$ & 0 & 4 & 11 & 0 \\
Mean \pm SD & 0 & 8 & 10 & 0 \\
\hline RSD & $0 \pm 0$ & $6,6 \pm 2,3094$ & $10,6 \pm 0,57735$ & $0 \pm 0$ \\
\hline
\end{tabular}


The results of phytochemical screening showed that the ethanol extract of Rosemary leaves positively contained flavonoids, alkaloids, and saponins. This result was due to the length of the maceration time of the Rosemary leaf, which influenced the yield of flavonoid, alkaloid and saponin extracted in ethanol extract of Rosemary leaves. The maceration time of Rosemary leaves was two days with a multilevel maceration method.

Rosmarinic acid in the ethanol extract of the Rosemary leaf is then made in several concentrations for subsequent MIC testing in vitro. The ethanol extract of Rosemary leaves was made into several concentrations of the test solution, namely concentrations of $10 \%(\mathrm{~b} / \mathrm{v}), 20 \%(\mathrm{~b} / \mathrm{v})$, $40 \%(\mathrm{~b} / \mathrm{v})$, and $80 \%(\mathrm{~b} / \mathrm{v})$ by adding CMC solution $1 \%$ with the aim of reducing the concentration of ethanol extract. Then the concentration that has been made is used in the MIC test.

Testing for the minimum inhibition level was carried out by the streak plate technique. The purpose of the MIC test is to determine the smallest concentration of ethanol extract, which can still inhibit the growth of Candida albicans. The results of the MIC test showed that all concentrations of ethanol extract contained fungal growth of Candida albicans on the surface of the fungus. The concentration of $80 \%(\mathrm{~b} / \mathrm{v})$, showed a greater antifungal activity. Furthermore the MIC was shown by $80 \%$ $(b / v)$ concentration of the ethanol extract of Rosemary leaves against Candida albicans. MIC of ethanol extract of Rosemary leaves is the basis of consideration for testing antifungal activity against Candida albicans.

Testing of antifungal activity of ethanol extract of Rosemary leaves using the disc method. The diffusion method has advantages compared to other dispersion methods, including easier and simpler implementation. The results of the antifungal activity test of Rosemary leaf ethanol extract showed the presence of inhibitory diameter in the ethanol extract of Rosemary leaf concentration of $80 \%(\mathrm{~b} / \mathrm{v})$ was $10.6 \pm 0.57735$ and RSD was $5.774 \%$. While the results of the antifungal activity test of the Rosemary leaf ethanol extract concentration of $100 \%$ did not have an inhibitory diameter in the fungus Candida albicans, it is not certain that Rosemary ethanol extract at a concentration of $100 \%$ does not have antifungal activity. Factors such as the addition of $1 \% \mathrm{CMC}$, which aims to close the active substance as an antimicrobial, can be considered. Because the ethanol extract of $100 \%$ Rosemary leaves did not add 1\% CMC. Another factor that could be the possibility of $100 \%$ Rosemary leaf ethanol extract does not have an inhibitory effect on Candida albicans, namely the ethanol extract of Rosemary leaves still contains many complex compounds, primary metabolites and other secondary metabolites that can cause fungal growth. So that further research is needed regarding the compound components in the ethanol extract of Rosemary leaves.

Alkaloids are compounds that have antimicrobial activity, which inhibits esterase and also DNA and RNA polymerase, also inhibits cell respiration and plays a role in DNA interactions. ${ }^{[9]}$ Ethanol extract of Rosemary leaves also has other secondary metabolites, which is flavonoids belonging to the phenol group. Flavonoid compounds have been reported has an antifungals effect. Flavonoid has a mechanism that can interfere with the process of food diffusion into cells so that fungal growth stops or until the fungus dies. ${ }^{[9,10]}$

The test continued with data analysis performed using special statistical software. The method used consists of two types, namely One-way ANOVA, in the analysis of antifungal activity data to express the degree of difference and linear regression to express the degree of relationship between the two variables. Because the data that is owned is less than 50 , the normality output 
from the Shapiro-Wilk test on SPSS is seen. The results of the normality obtained a value of $p=0.001$. Because of the value of $\mathrm{p}<0.05$, the conclusion is that the antifungal activity test at a concentration of $80 \%(\mathrm{~b} / \mathrm{v})$ and positive control is not normally distributed. While the negative control and ethanol extract of 100\% concentration in SPSS were eliminated due to the absence of an inhibitory diameter and were read to have consistent data. Then Homogeneity testing was carried out on SPSS, which aimed to see the data. There were significant differences in proportions between the two groups of data.

With the SPSS test, Homogeneity data shows the data obtained by the value $\mathrm{p}=$ 1,000 on Tukey and Duncan. Because the value of $p>0.05$, it was concluded that the data on the value of the antifungal activity test had no significant proportional differences between the two groups of data. Thus, the terms of the ANOVA test are not fulfilled where the requirements on the ANOVA test are data that are normally distributed and Homogeneous. Therefore a decision was made to use the alternative test, namely the Kruskal-Wallis test, to see any significant differences between the two test groups.

The SPSS test with the Kruskal-Wallis test is used for the comparative hypothesis test of the numerical variable abnormal distribution of more than two unpaired groups. With the Kurskal-Wallis test obtained a significant value of $p=0.001$. Because of the value of $p<0.05$, it was concluded that the data on the value of antifungal activity test there were two groups of data that had significant mean differences, to find out which groups were significantly different. In testing the hypothesis by testing the Kruskal-Wallis have a mean rank output that shows the average rating of each treatment. In the antifungal activity test data, it has an average rating output of 32 at the Rosemary leaf ethanol extract concentration of $80 \%$ $(b / v)$ higher than the average positive control rating, which has an average rating of 23. Where this result states that ethanol extract Rosemary leaves with a concentration of $80 \%(\mathrm{~b} / \mathrm{v})$ was better than ketoconazole.

The post-Hoc analysis concluded that the data on the value of the antifungal activity test had no significant difference. Whereas for the value of $\mathrm{p}<0.05$, it was concluded that the test data for the antifungal activity had a significant difference. The results of negative control with $100 \%$ Rosemary leaf ethanol extract obtained a significant value of 1,000 with the interpretation of the results were no significant differences. While the results between positive controls and ethanol extract of $100 \%$, Rosemary leaves obtained a significant value of 0,000 with the interpretation of the results were significant differences. These results indicate that the ethanol extract of Rosemary leaves with a concentration of $100 \%$ can not inhibit the growth of fungi Candida albicans.

The results of other Post Hoc tests were also shown in the ethanol extract of Rosemary leaves at a concentration of $80 \%$ (b / v). The results between negative controls with Rosemary leaf ethanol extract $80 \%$ (b/v)obtained a significant value of 0,000 with the interpretation of the results were significant differences. While the results of positive controls with Rosemary leaf ethanol extract $80 \%$ (b/v)obtained a significant value of 0,000 with the interpretation of the results were significant differences. These results are due to the results of the inhibitory diameter between the positive control with Rosemary leaf ethanol extract concentration of $80 \%$ (b/v)has a diameter greater than the positive control. Rosemary leaf ethanol extract concentration of $80 \%(\mathrm{~b} / \mathrm{v})$ has a better inhibitory effect compare to ketoconazole.

\section{CONCLUSION}

Ethanol extract of Rosemary leaves (Rosmarinus officinalis L.) has an inhibitory effect on Candida albicans fungi 
at $80 \%(\mathrm{~b} / \mathrm{v})$ concentration, but it is not able to inhibit Candida albicans at a concentration of $100 \% \quad(b / v)$. The concentration of ethanol extract of Rosemary leaves (Rosmarinus officinalis L.) with a concentration of $80 \%(\mathrm{~b} / \mathrm{v})$ can be a candidate for drug development as an inhibitor of TTM-RTPase in the capping process on the fungus Candida albicans.

\section{CONFLICT OF INTEREST}

This paper was written independently. All authors disclose no financial or personal relationships with other people or organizations that could inappropriately influence the work.

\section{ACKNOWLEDGEMENT}

We thank to lecturers and staff in department of Pharmacy, Universitas Bali Internasional and department of Pharmacy, Faculty of Math and Science, Udayana University, Bali Indonesia for the support in the implementation of research.

\section{REFERENCES}

1. Pelczar, Michael J. Chan, E.S.C. Pelczar, Merna.F. Hadioetomo, Ratna.S. Imas,T. Tjitrosomo, S.S. Angka, S.S. Dasar-Dasar Mikrobiologi. Jakarta, UI Press; 2006.

2. Lutfiyanti, Rosiska. Widodo, F.M. Eko, N.D. Aktivitas Antijamur Senyawa Bioaktif Ekstrak Gelidium Latifolium Terhadap Candida albicans. Semarang. Jurnal Pengobatan dan Bioteknologi Hasil Perikanan; 2012.

3. American Thoracic Society (ATS). Candida Infection of the BloodstreamCandidemia. Am J Respir Crit Care Med. 2012; 185(1) : 3-4.

4. Whaley Sarah G, Berkow, Elizabeth L, Rybak, JeffreyM, AndrewT.N, Barker, Katherine S. and Rogers, P.David.
Azole Antifungal Resistance in Candida albicans and EmergingNonalbicans Candida Species. Microbiol; 2017.

5. Permadi, A. Susanto dan Wardatun, Sri. Perbandingan Metode Ekstraksi Bertingkat Dan Tidak Bertingkat Terhadap Flavonoid Total Herba Ciplukan (Physalis Angulata L.) Secara Kolorimetri: Bogor, Indonesia. Universitas Pakuan; 2015.

6. Peng, CH. Jeng De S.U. Chyau, C.C. Sung, T.Y. Shien H.O. Chiung-Chi Peng \& Robert Y. Peng. Supercritical Fluid Extracts of Rosemary Leaves Exhibit Potent Anti-Inflammation and Anti-Tumor Effects. Taipe. Taiwan. Biosci. Biotechnol. Biochem. 2007.

7. El-Esawi MA, Elansary HO, ElShanhorey NA, Abdel-Hamid AME, Ali HM and Elshikh MS. Salicylic Acid-Regulated Antioxidant Mechanisms and Gene Expression Enhance Rosemary Performance under Saline Conditions. Front. Physiol; 2017.

8. Fredman, Tal, ND. The Effect of Rosmarinic Acid on Immunological and Neurological Systems: A Basic Science and Clinical Review. Journal of Restorative Medicine. 2015; 4(1) : 50-55.

9. Zakiah, Ariza I. Uji aktivitas anti jamur ekstrak etanol daun mangga bacang (mongifera foetida L.) terhadap Candida albicans secara invitro. Universitas Tanjung Pura. Pontianak; 2014.

10. Kurniawan. Uji aktivitas anti jamur ekstrak etanol daun kelor (Moringa oleifera lamk) terhadap Candida albicans secara invitro. Universitas Tanjung Pura. Pontianak; 2015. 